\title{
BIOLOGICAL ASPECTS AND LIFE TABLE PARAMETERS OF THE PREDACIOUS MITE, AGISTEMUS EXSERTUS GONZALEZ (ACARI: PROSTIGMATA: STIGMAEIDAE) FED ON FIFE FOOD TYPES
}

\author{
Alyaa A. Tawfik \\ Plant Protection Research Institute, A. R. C., Dokki, Giza, Egypt. \\ Corresponding author Email :Dr_Alyaa_Abdelkader@yahoo.com
}

Received: Feb. 14, 2018

Accepted: Mar. 12, 2018

\begin{abstract}
The biology of Agistemus exsertus Gonzalez was studied using five different types of diets, eggs and nymph of Tetranychus urticae Koch, eggs and larva of Bemisia tabaci, and eggs of Ephestia kuehniella as the food source. The development was faster and reproduction was higher when A. exsertus fed on eggs of E. kuehniella. A diet of T.urticae, eggs provided the longest female longevity and mean total fecundity which resulted in the highest net reproductive rate $\left(R_{0}\right)$ value (93.71), intrinsic rate of natural increase $\left(r_{m}=0.25\right)$, finite rate of increase $\left(e^{r m}=1.28\right)$ per day, and Gross reproduction rate $(G R R=104.8)$ for $A$. exsertus. whereas the lowest value of all parameters achieved with a diet of $B$. tabaci larva.
\end{abstract}

Key words: Acari, Agistemus exsertus, Tetranychus urticae, Bemisia tabaci, Ephestia kuehniella, life table.

\section{INTRODUCTION}

Mites of the family Stigmaeidae are considered predators of mites which found in the soil, stored products, and plants (Momen, 2001). Most of them are effective and widespread predators that react a basic role in the biological control of phytophagous mites (Nawar, 1992). Agistemus exsertus Gonzalez considerable the most common stigmaeid mite species collected from fruit trees, vegetables, ornamentals and field crops (Fouly and Al- Rehiayani 2011). The predacious mite $A$. exsertus feeds on several diets not only tetranychid mites, pollen grains, eriophyid and tenuipalpid mites (EIBagoury and Reda, 1985; Santos and Laing, 1985) but also the eggs of both white-flies (Khan, et al., 2016) and stored product moth Ephestia kuehniella Zeller (Momen, 2001). Therefore, The major objective of this study was to determine the effect of several types of diets on the biological aspects and life table parameters of $A$. exsertus.

\section{MATERIALS AND METHODS \\ Maintenance of mite stock cultures:}

Adult females of $A$. exsertus utilized within this study were picked up carefully from vigorously swarmed Ploughman's spikenard plant In Dakahlia Governorate, Egypt during 2017; and reared on eggs and immature stages of the two-spotted spider mite Tetranychus urticae Koch at $27^{\circ} \mathrm{C}$ and $70 \pm 5 \%$ R. $\mathrm{H}$.

\section{Diets:}

Five diets were evaluated for their effect on development survival, oviposition, and life table parameter: (Eggs and nymph of the two- spotted spider mite T.urticae were reared at the laboratory, Eggs and larva of the whitefly, B. tabaci were obtained from heavy infestation of beans, Phaseolusvulgaris. and the eggs of the stored product moth E. kuehniella were obtained from stock culture kept at the laboratory for many years). 


\section{Effects of diet on development:}

The rearing arena $(3 \times 3 \mathrm{~cm})$ from claiming excised raspberry leaves, put on immersed cotton over plastic Petri dishes, were used to keep the predator. A strip of moistened absorbent cotton might have been put around the outside edge of the leaves. A single recently deposited egg might have been exchanged to each arena and the recently hatched larvae were supplied with the food resource to be evaluated. All handling of mites and host eggs was performed with a very fine, moistened, squirrel hairbrush. Arenas were inspected every day and predator improvement Also survival were recorded. Prey eggs consumed devoured were traded every day toward new eggs should keep up a plentiful food supply.

Recently emerged female, mated, restricted separately around test arenas, alongside with the food to be tested. A few strands of cotton wool were given concerning illustration an ovipositor site in each arena. Oviposition and survival parameters were recorded additionally, stigmaeid eggs uprooted every day for sex determination. Twenty- five eggs of A. exsertus for each analyze were observed daily.
Life table parameters as defined by Birch (1948) were calculated according to A BASIC computer program (Abou-Setta et al., 1986).

\section{RESULTS AND DISCUSSION}

Effects of diet on development :

Individuals of $A$. exsertus successfully developed from larva to adult when fed on all kinds of food. Data in the Table (1) showed that there were no significant between the incubation period of the egg when $A$. exsertus fed on nymph of T.urticae, Eggs, and larva of B. tabaci, and eggs of $E$. kuehniella. which were 2.4, 2.3,2.0, and 2.0 days respectively.But, it was significant when fed on the egg of T.urticae which was 1.4 days. The life cycle of $A$. exsertus had the same trend when fed on the 5 types of dites. Although, the adult longevity of $A$. exsertus was differed significantly among the various kinds of food. Adult longevity was too longer when fed on the eggs of T.urticae that was 29.5 days and decreased to 26.2, 22.9 , and 20.1 days when fed on the eggs of E. kuehniella, nymph of T.urticae, and eggs of B. tabaci, respectively, while it was too shorter when fed on the larvae of $B$. tabaci, which durated 13.2 days.

Table (1): Comparative duration (x \pm S.D.) of the female of $A$. exsertus on different kinds of food at $27 \pm 2{ }^{\circ} \mathrm{C}$ and $70 \pm 5 \%$ R.H.

\begin{tabular}{|c|c|c|c|c|c|c|}
\hline $\begin{array}{c}\text { Developmental } \\
\text { stages }\end{array}$ & $\begin{array}{c}\text { T. urticae } \\
\text { (eggs) }\end{array}$ & $\begin{array}{l}\text { T. urticae } \\
\text { (nymph) }\end{array}$ & $\begin{array}{c}\text { B. tabaci } \\
\text { (eggs) }\end{array}$ & $\begin{array}{l}\text { B. tabaci } \\
\text { (larva) }\end{array}$ & $\begin{array}{c}\text { E. kuehniella } \\
\text { (eggs) }\end{array}$ & L.S.D \\
\hline Egg & $1.4^{c} \pm 0.50$ & $2.4^{\mathrm{a}} \pm 0.50$ & $2.3^{\mathrm{a}} \pm 0.47$ & $2.0^{b} \pm 0.56$ & $2.0^{b} \pm 0.56$ & 3.84 \\
\hline Larva & $1.6^{c} \pm 0.50$ & $2.6^{a} \pm 0.51$ & $2.4^{a} \pm 0.50$ & $2.3^{a} \pm 0.47$ & $2.1^{b} \pm 0.64$ & 1.18 \\
\hline Protor & $1.8^{d} \pm 0.41$ & $2.4^{c} \pm 0.49$ & 2.4 & \pm 0.83 & $=0.64$ & 1.61 \\
\hline Deutonymph & $3.3^{c} \pm 0.47$ & $4.4^{b} \pm 0.49$ & $3.9^{c} \pm 0.67$ & $5.2^{a} \pm 0.70$ & $4.5^{b} \pm 0.51$ & 1.26 \\
\hline Life cycle & $8.1^{\mathrm{c}} \pm 1.07$ & $11.7^{b} \pm 0.68$ & $11.1^{b} \pm 1.23$ & $12.3^{a} \pm 1.08$ & $12.5^{a} \pm 1.28$ & 1.92 \\
\hline $\begin{array}{c}\text { Preoviposition } \\
\text { period }\end{array}$ & 1.8 & $3.5^{2}$ & $3.3^{a}=$ & 2.2 & 2. & 1.03 \\
\hline $\begin{array}{c}\text { Oviposition } \\
\text { period }\end{array}$ & 24.3 & $16.8^{\mathrm{c}}$ & 14.6 & 8.5 & 20. & 3.42 \\
\hline $\begin{array}{c}\text { Adult } \\
\text { longevity }\end{array}$ & 29. & $22.9^{c} \pm 1.88$ & $20.1^{c} \pm 2.04$ & \pm 1.70 & $26 . .2^{b} \pm 1.95$ & 3.69 \\
\hline Life span & $37.6^{a} \pm 2.91$ & $34.6^{b} \pm 1.98$ & $31.1^{c} \pm 2.43$ & $25.5^{d} \pm 1.96$ & $38.7^{a} \pm 2.43$ & 3.82 \\
\hline
\end{tabular}

Means followed by the same letter in the same raw are not significantly different at 0.01 level. 
These data were in agreement with (Momen, 2001), who used a diet of $E$. kuehniella (eggs) which provided the longest female longevity and mean total fecundity. Rasmy et al., 1987, reported that $A$. exsertus has been reported to feed on dates pollen and the acarid mite Tyreophagous casei Oudemans and the daily rate of reproductively averaged $\mathbf{3 . 0}$ eggs $l^{\circ}+l$ day for both diets.

Data illustrated in Fig. (1) proved an actual compared with both life cycle and life span of $A$. exsertus when fed on the fife types of food under the same conditions $27 \pm 2^{\circ} \mathrm{C}$ and $70 \pm 5 \%$ R.H at the laboratory.

The life cycle of $\boldsymbol{A}$. exsertus recorded the longest period when fed on nymphs of T.urticae, eggs, and larvae of B. tabaci, and eggs of $E$. kuehniella.On the other hand, when the predacious mite fed on the eggs of T.urticae, the life spanof A. exsertus had the same trend, Momen, 2001. In addition, Momen (2001) reporetd that the development was faster and reproduction was higher when A.exsertus fed on eggs of E.kuehniella. A total of 97.78 and 75.27 eggs per female were obtained when eggs of E.kuehniella and $P$. zizyphus were provided respectively.

\section{Effects of diet on the life table parameters:}

Data in Table (2) showed that, the highly net reproduction rate (R0) of $A$. exsertus females occurred with adite of T.urticae eggs which were 93.71 females per female, whereas the lower value of (R0) was $\mathbf{1 3 . 1 6}$ females per female with a dite of T.urticae larva. Mean generation time (T) of $A$. exsertus did not very much between the fifth diets mentioned before.

The intrinsic rate of increase $(\mathrm{rm})$ and, subsequently, the finite rate of increase (erm )were relatively equal between all types of food . ( $\mathrm{rm})$ meager between 0.14 and 0.25 while (erm) was between 1.15 and 1.28. The highest value of $a$ developmental rate $(0.15)$ was obtained with a dite of T.urticae eggs, whereas the other diets relatively equal.

The highest Gross Reproduction Rate (GRR) (104.8) occurred with a dite of T.urticae eggs but the lowest ( 14.76) was recorded with a dite of $B$. tabacilarva.

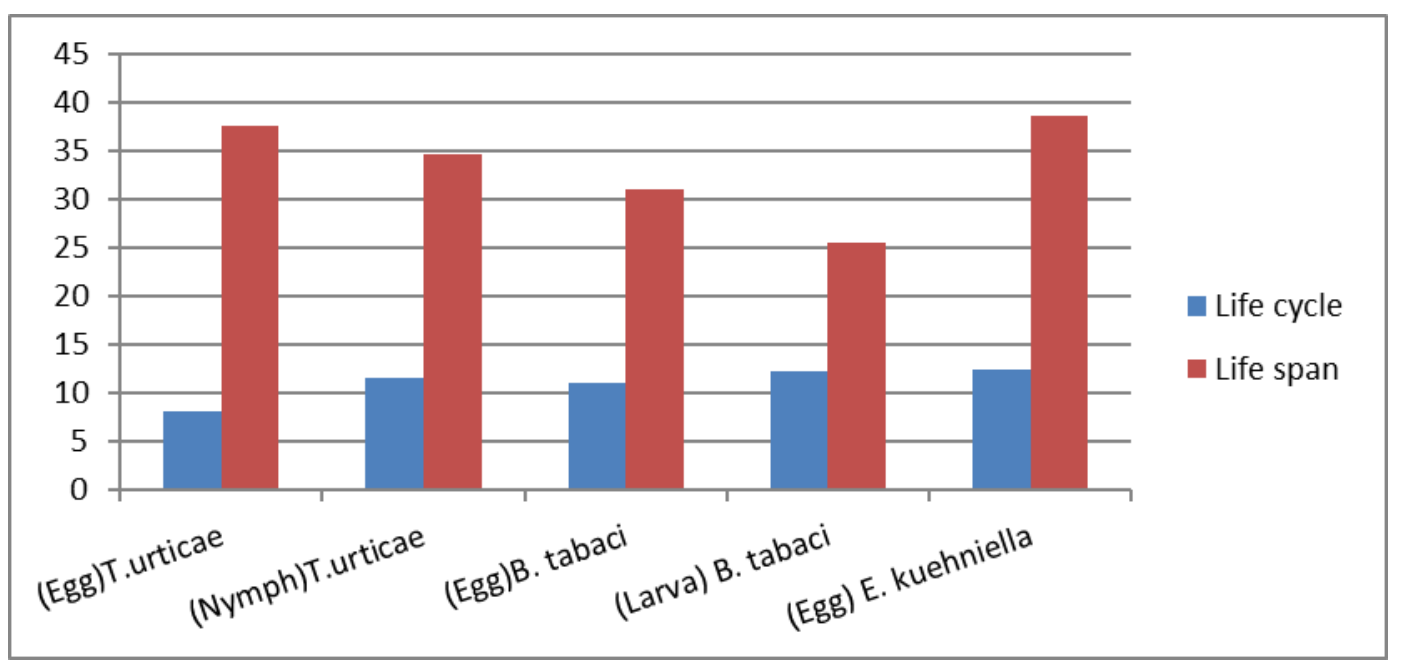

Fig (1): Comparative between life cycle and life span of $A$. exsertus females at different kinds of food at $27 \pm 2^{\circ} \mathrm{C}$ and $70 \pm 5 \%$ R.H. 
Table ( 2 ): Life Table Parameters of $A$. exsertus females at different kinds of food at 27士 $2^{\circ} \mathrm{C}$ and $70 \pm 5 \%$ R.H.

\begin{tabular}{|c|c|c|c|c|c|}
\hline \multirow[b]{2}{*}{ Parameters } & \multicolumn{5}{|c|}{ Prey species } \\
\hline & $\begin{array}{c}\text { T.urticae } \\
\text { (eggs) }\end{array}$ & $\begin{array}{l}\text { T.urticae } \\
\text { (nymphs) }\end{array}$ & $\begin{array}{c}B . \\
\text { tabaci } \\
\text { (eggs) }\end{array}$ & $\begin{array}{c}\text { B. } \\
\text { tabaci } \\
\text { (larvae) }\end{array}$ & $\begin{array}{c}E . \\
\text { kuehniella } \\
\text { (eggs) }\end{array}$ \\
\hline Net reproduction rate $\left(R_{0}\right)$ & 93.71 & 31.86 & 29.66 & 13.16 & 46.60 \\
\hline Mean generation time $(T)$ & 18.17 & 22.71 & 20.82 & 18.18 & 23.41 \\
\hline Intrinsic rate of increase $\left(r_{m}\right)$ & 0.25 & 0.15 & 0.16 & 0.14 & 0.16 \\
\hline Finite rate of increase $\left(\mathrm{e}^{\mathrm{rm}}\right)$ & 1.28 & 1.16 & 1.18 & 1.15 & 1.18 \\
\hline $\begin{array}{l}\text { Generation doubling time } \\
\left.\text { (DT= } \ln 2 / r_{m}\right)\end{array}$ & 5.66 & 9.43 & 8.84 & 10.10 & 8.84 \\
\hline Developmental rate & 0.15 & 0.11 & 0.11 & 0.10 & 0.10 \\
\hline $\begin{array}{c}\text { Gross reproduction rate } \\
\text { (GRR) }\end{array}$ & 104.8 & 35.67 & 33.26 & 14.76 & 51.92 \\
\hline
\end{tabular}

Abou-Awad and El-Sawi, 1993, studied the intrinsic rate ofincrease which was higher on the diet as E. Kuehniella eggs over the individuals for tetranychoid compared with whitefly eggs.

Bruce-Oliver and Hoy, 1990, showed that the eggs of E. Kuehniella was the favoriate for the most of predacious mites. The finite rate of increase $\left(e^{r m}\right)$ were relatively higher $(0.196$ and 1.22 respectively) when individuals were fed $E$. kuehniella eggs and lower when fed $P$. zizyphus eggs (0.174 and 1.19). The higher $\left(r_{m}\right)$ for $A$. exsertus reared on eggs of $E$. kuehniella could be attributed to differences in nutritive quality (Bruce et al., 1990).

\section{REFERENCES}

Abou-Awad, B. A. and S. A. El-Sawi (1993). Biology and life table of the predacious mite, Agistemus exsertusGonz. (Acari : Stigmaeidae)
Anz.fürSchädl., Pflanz., Umwelt. 66, 101-103.

Abou-Setta, M. M., R. W. Sorrell and C. C. Childers (1986). Life 48: A basic computer programme to calculate life table parameters for an insect or mite species. Fla. Entomol. 69, 690-697.

Birch, L. C. (1948). The intrinsic rate of natural increase on an insect population. J. Anim. Ecol. 17, 15-26.

Bruce-Oliver, S. J. and M. A. Hoy (1990). Effect of prey stage on life-table attributes of a genetically manipulated strain of Metaseiulus occidentalis (Acari : Phytoseiidae). Exp. App. Acarology 9, 201-217.

El-Bagoury, M.E. and A.S. Reda (1985). Agistemus exsertus Gonzalez (Acarina: Stigmaeidae) as a predator of the ploughman's spikenard gall mite, Eriophyes dioscuridis (Eriophyidae) Bull. Fac. Agric. Univ. of Cairo 36, 571-576. 
Momen, F.M. (2001). Effect of diet on the Biology and life tables of the predacious mite Agistemus exsertus (Acari: Stigmaeidae). Acta phytopathologica et Entomologica Hungarica 36(1-2): 173 - 178.

Fouly, A.H. and S.M. Al-Rehiayani (2011). Predaceous mites in Al-Qassim region, Saudi Arabia with a description of two new laelapid species (Acari: Gamasida: Laelapidae). J. Entomol.8P139-151.

Khan, B.S., M. Afzal, M.H. Bashir, M. Farooq and A. Ghaffar (2016). A new predatory mite species of the genus Agistemus (Agistemus: Layyahensis) Stigmaeidae: Acari from Punjab, Pakistan. Adv Plant Agric. Res. 4(6): 161-166.
Nawar, M.S. (1992). Effect of prey density on predaceous efficiency and oviposition of Agistemus exsertus (Acari: Stigmaeidae). Experimental \& Applied Acarology, 15: 141-144.

Rasmy, A. H., M. E. El-Bagoury and A. S. Reda (1987). A new diet for reproduction of two predacious mites Amblyseius gossipi and Agistemus exsertus (Acari: Phytoseiidae: Stigmaeidae). Entomophaga 32, 277280.

Santos, M. A. and L. E. Laing (1985). Stigmaeid predators. In Helle, W., and Sabelis, M. W. (eds.) Spider mites Their biology, natural enemies, and control. Elsevier, Amsterdam. Vol. 1B, 197- 203. 
Agistemus exsertus الخصائص البيولوجية وجداول الحياة للمفترس الأكاروسى Gonzalez (Acari : Prostigmata: Stigmaeidae) خمسة انواع من الغذاء

\author{
علياء عبد القادر توفيق
}

معه بحوث وقاية النباتات - مركز البحوث الزراعية - الاقى - الجيزة - مصر

الملخص العريى (المربى

Agistemus exsertus Gonzalez (Acari : أجريت الدراسات البيولوجية للففترس الاكاروسى بتغذيته على خمس انواع مختلفة من التغذيه وهى : بيض وحوريات العنكبوت الاحمر ذو البقعتين ، و بيض ويرقات الذبابة البيضاء ،و بيض فراثة الحبوب المخزونة كمصادر اساسية للغذاء. و من

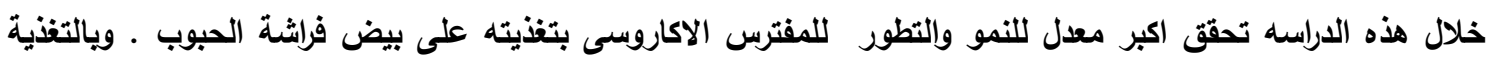

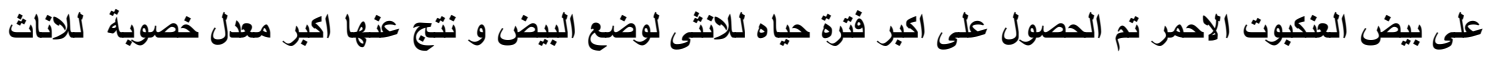

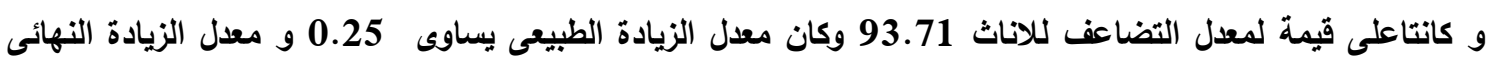
يساوى 1.28/ انثى / يوم ، و كان اجمالى معدل الانتاج/ انثى خلال مدة حياتها خلال جيل واحد يساوى 104.8 ،

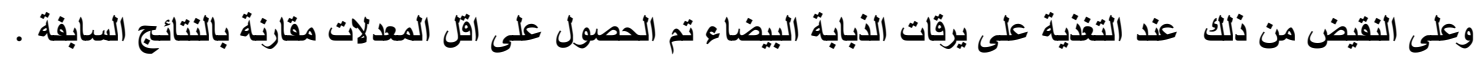


Biological aspects and life table parameters of the predacious mite, ........... 